\title{
Nesting ecology of Chelonia mydas (Testudines: Cheloniidae) on the Guanahacabibes Peninsula, Cuba
}

\author{
Julia Azanza Ricardo ${ }^{1 *}$, María E. Ibarra Martín¹, Gaspar González Sansón¹, F. Alberto Abreu
}

Grobois $^{2}$, Karen L. Eckert ${ }^{3}$, Georgina Espinosa López ${ }^{4} \&$ Ken Oyama ${ }^{5}$

1. Centro de Investigaciones Marinas, Universidad de La Habana, 16 \#114, CP 11300, Playa, Ciudad Habana, Cuba; julia@cim.uh.cu,cim@cim.uh.cu,ggsanson@yahoo.es

2. Unidad Mazatlán, Instituto de Ciencias del Mar y Limnología UNAM, CP 811, Mazatlán, Sinaloa 82000, México; alberto.abreu@ola.icmyl.unam.mx

3. WIDECAST, 1348 Rustic view Drive Ballwin, Missouri CP 63011, USA; keckert@widecast.org

4. Facultad de Biología, Universidad de La Habana, 25 \# 10, CP 10400, Plaza, Ciudad Habana, Cuba; georgina@fbio.uh.cu

5. Centro de Investigaciones en Ecosistemas y Escuela Nacional de Estudios Superiores Unidad Morelia, UNAM, Antigua carretera a Pátzcuaro 8701, Col. Ex Hacienda de San José de la Huerta CP 58190, Morelia, Mexico; akoyama@oikos.unam.mx

* Corresponding author

Received 11-X-2012. C Corrected 10-II-2013. $\quad$ Accepted 18-III-2013.

\begin{abstract}
The nesting colony of green sea turtles (Chelonia mydas) at Guanahacabibes Peninsula Biosphere Reserve and National Park is one of the largest in the Cuban archipelago; however, little information about its nesting ecology is available. Temporal and spatial variation in nesting and reproductive success as well as morphometric characteristics of gravid females were used to ecologically characterize this colony. Nine beaches of the Southernmost coast of Guanahacabibes Peninsula were monitored for 14 years (1998-2012) to determine green turtle nesting activity, from May to September (peak nesting season in this area). Beach dimensions were measured to determine nest density using the length and the area. Afterward the beaches were divided in two categories, index and secondary. Females were measured and tagged to compare new tagged females (823) with returning tagged females (140). Remigration interval was also determined. Temporal variation was identified as the annual number of nesting emergences and oviposits per female, with apparent peaks in reproductive activity on a biennial cycle in the first six years followed by periods of annual increase in nest number (2003-2008) and periods of decreasing number of nests (2010-2012). We also found intra-seasonal variation with the highest nesting activity in July, particularly in the second half of the month. The peak emergence time was 22:00-02:00hr. In terms of spatial variation, smaller beaches had the highest nest density and nesting was more frequent 6-9m from the high tide line, where hatchling production was maximized although hatchling success was high on average, above $80 \%$. Morphometric analysis of females was made and newly tagged turtles were smaller on average than remigrants. Our results are only a first attempt at characterizing Guanahacabibes' populations but have great value for establishing conservation priorities within the context of national management plans, and for efficient monitoring and protection of nesting beaches.Rev. Biol. Trop. 61 (4): 1935-1945. Epub 2013 December 01.
\end{abstract}

Key words: green turtle, nesting ecology, reproductive success, Cuba.

The extensive Cuban archipelago contains a wide variety of habitats suitable for the development, foraging and reproduction of different species of marine turtles (Moncada \& Nodarse, 1983), among them, the green turtle Chelonia mydas (Linnaeus, 1758). Despite the fact that, within the Caribbean region, Cuba is home to important breeding habitats (Nodarse et al., 2002), there is little information about Cuban populations of this endangered species (IUCN Red List, 2001). C. mydas nesting in Cuba mostly occurs along the Southern coastlines of the Cuban archipelago, where the archipelagos of Jardines de la Reina and Los Canarreos are 
considered the main nesting areas for Cuban green turtles (Nodarse, Moncada, Meneses \& Rodríguez, 2000). Guanahacabibes Peninsula (Ibarra et al., 2002), on the Western tip of Cuba is another important green turtle nesting area.

Prior to 1998, most research on green turtle nesting ecology in Cuba was focused on El Guanal beach (Isla de la Juventud), where long-term observations were conducted (19821996) on the distribution and abundance of annual nesting efforts (Nodarse et al., 2000, 2002). In 1998, the Marine Research Center of the University of Havana initiated a research project at Guanahacabibes Peninsula, the Western most region of the Cuban archipelago, an area that is strategically positioned on the main oceanic current of the Western Caribbean region. Guanahacabibes is also a National Park and a UNESCO Biosphere Reserve. These studies of C. mydas continue and include ecological studies of the loggerhead turtle, Caretta caretta (Linnaeus 1758) (Martín et al., 1999; Ibarra et al., 2000, 2002), as well as the nation's first genetic studies of both species (Espinosa et al., 1999).

Guanahacabibes Peninsula is a protected area with national and international relevance and hosts one of the largest green turtle colonies in Cuba (Azanza, 2009). In addition to other flora and fauna it is a highly important site for the conservation of natural resources. This study represents the first description of the C. mydas nesting colony in the area and our objectives were to determine: a) temporal and spatial variations in nesting ecology and b) morphometric characteristics of gravid females.

\section{MATERIALS AND METHODS}

Study area: The study was carried out on nine beaches located on the Southernmost coast of the Guanahacabibes Peninsula (21 ${ }^{\circ} 59^{\prime}$, $22^{\circ} 00^{\prime} \mathrm{N}-84^{\circ} 44^{\prime}, 8^{\circ} 50^{\prime} \mathrm{W}$ ) (Fig. 1). The selection of the beaches was based on preliminary field surveys designed to identify: (1) the most prominent beaches for systematic monitoring and (2) those beaches with secondary nesting levels for less intensive study. Informing this assessment were discussions with local residents regarding distribution and relative abundance of green turtles (Martín et al., 1998).

Sampling design: Data was collected from 1998 to 2012, however 1998 and 1999 were only considered for analyses of temporal

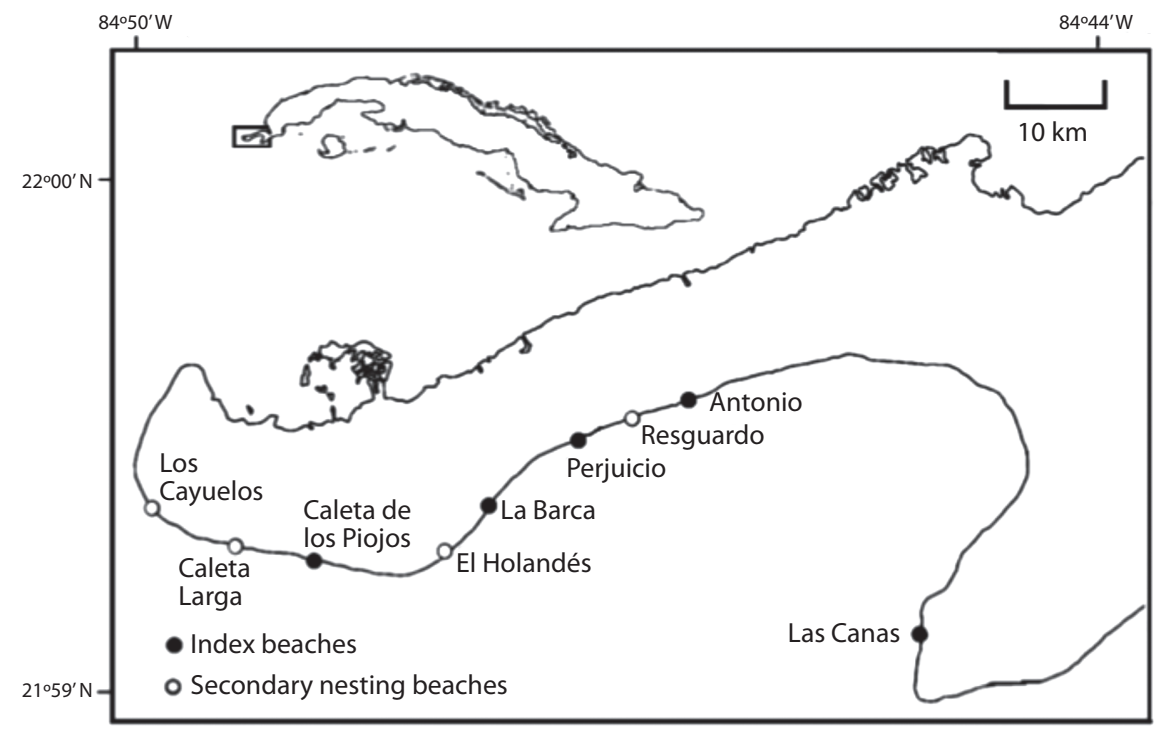

Fig. 1. Studied beaches in Guanahacabibes Peninsula, Cuba. 
variation as systematic work at the five index beaches began in 2000. We considered high nesting seasons to be those with more than 300 nests, moderate season if there were between 150 and 300 nests, and low seasons to be those with less than 150 .

In 1998 we estimated the number of emergences and nests at beaches that were not systematically monitored, and used these to reference the values observed at Antonio Beach in different years to determine proportional values for the other beaches in 1998. We also estimated the number of nesting females by dividing the number of nests by the mean number of nests per female in the area (2.01). Reproductive seasons were divided in 15 day intervals to determine with precision the reproductive peak. The first interval was the second half of May and the last interval, number VIII, took place in the first half of September.

Beaches were patrolled nightly (from 21:00-06:00hr) at $30-45 \mathrm{~min}$ intervals from the second half of May through the first half of September, which marks the nesting season of the green turtle reported by Márquez (1996) for the Caribbean Region, and corroborated by our surveys. All females encountered were measured and flipper-tagged (Balazs, 1999). Following Bolten (1999), we measured curved carapace length (CCL) notch-to-notch from the anterior point at midline (nuchalscute) to posterior notch at midline between the supracaudals, using a metric tape $(1 \mathrm{~mm}$ resolution). Straight carapace length (SCL) notch-to-tip was measured from the anterior point at midline (nuchalscute) to the posterior tip of the supracaudals using a caliper $(1 \mathrm{~mm}$ resolution). Width was measured from opposite marginal scutes of the widest region of the carapace. Turtles were front-flipper tagged using steel-inconel style $681 \mathrm{C}$ tags embossed with the suffix ' $\mathrm{HV}$ ' followed by four serial digits (beginning with 0001) from National Band and Tag Company, USA. Since the tagging program started in 2001 through present, turtles are been tagged every night during the monitoring season in four of the index beaches (Antonio, Perjuicio, La Barca and Caleta de los
Piojos). Nevertheless, due to logistic problems, monitoring activity in 2009 was very limited, and since that year, nocturnal monitoring and tagging was not continued in the secondary beaches and at Las Canas index beach.

Each nest was identified by a rope inside the nest attached to a labelled pole placed 0.5$1.0 \mathrm{~m}$ from the nest. All female emergences were counted along with the number of nests. Two measurements of nest density were used. The first density measurement took into consideration that each beach had an area equivalent to a rectangle defined by the beach length and the average width of the sand platform. Density was calculated by dividing the total number of nests by beach area. The second measurement is the most commonly used, and is calculated by dividing the total number of nests by beach length. This last measure was used for comparative purposes. Hatchling production was calculated by multiplying the mean hatched eggs by the total of nests in each distance interval. Hatchling success was determined as the number of hatchlings divided by the total egg number, all multiplied by 100 .

To determine whether the analysed variable fulfilled parameters, the Kolmogorov-Smirnov test was employed to determine normality of data and Bartlett's test was used for variance of homogeneity. The number of emergences by time intervals and the number of females by size class that did not have normal distributions were square root transformed and tested again. The number of females emerging per hour and their body sizes were analyzed by means of a one-way analysis of variance and, for multiple comparisons, the Student-Newman-Keuls test (SNK). For morphometric measures we also calculated descriptive statistic variables (N, mean, 95\% confidence interval, minimum and maximum. To compare frequency distribution of Curve Carapace Length of newly tagged and remigrant females, a Chi-square test was conducted, excluding size classes with no observations. The significance of the observed differences was evaluated with the program STATISTICA, version 6.0 for Windows. In each case, a level of significance of 0.05 was used. 


\section{RESULTS}

Nesting behaviour by green turtles on the Guanahacabibes Peninsula during 15 nesting seasons showed an early biennial pattern with relatively high nesting frequency ( $>300$ nests) in 1998, 2000, and 2002, and low frequency ( $<150$ nests) during 1999 and 2001. However, from 2003 the behaviour changed, with an annual increase in nesting until the year 2009, when the number of nests was similar to the years 1999 and 2001 (Table 1). Remigration interval also changed from two years before 2009 to three years afterwards. Despite remigration, the majority of tagged turtles every year were new and below the estimated number of nesting females.
In general, the number of emergences were well distributed with fewer activities at the beginning (May-June) and the end (September) of the season, and maximum activity in the middle (July and early August); therefore, only this second period was represented on the graphic (Fig. 2). In most years the highest activity occurred during the second half of July (2000 to 2006, 2010 and 2012). In the remaining years the highest activity occurred during the first half of the month.

Female emergences were observed during all nocturnal hours $(2100-0600 \mathrm{hr})$, peaking between 22:00 and 00:00hr and showing the least activity at dusk and dawn (Fig. 3, F $(11 ; 155)=12,19 ; \mathrm{p}<0,01)$.

TABLE 1

Crawls, nests and tagged females of green turtles (Chelonia mydas) at the Peninsula of Guanahacabibes, Cuba

\begin{tabular}{lccccccccccccccc} 
& \multicolumn{10}{c}{ Nesting season } \\
& 1998 & 1999 & 2000 & 2001 & 2002 & 2003 & 2004 & 2005 & 2006 & 2007 & 2008 & 2009 & 2010 & 2011 & 2012 \\
Crawls $^{1}$ & $87(530)$ & 40 & 603 & 79 & 844 & 318 & 233 & 370 & 474 & 521 & 716 & 30 & 420 & 315 & 291 \\
Nest $^{1}$ & $58(330)$ & 26 & 408 & 44 & 506 & 199 & 121 & 240 & 295 & 309 & 421 & 23 & 292 & 253 & 180 \\
Nesting females $^{165}$ & 13 & 204 & 22 & 253 & 100 & 60 & 120 & 148 & 154 & 210 & 11 & 146 & 126 & 90 \\
New taggs $^{2}$ & & & & 9 & 163 & 32 & 46 & 68 & 94 & 99 & 117 & 0 & 79 & 59 & 57 \\
Remigrants $^{2}$ & & & & 0 & 0 & 1 & 7 & 19 & 13 & 21 & 38 & 1 & 20 & 13 & 7 \\
Remigration interval & & & & & 1 & 2 & 2.85 & 2.46 & 2.36 & 2.29 & 2 & 3.33 & 3.15 & 3.43 \\
\hline
\end{tabular}

1. In parenthesis is presented estimated number of nests and crawls in 1998.

2. Total tagged females and number of remigrants are presented since 2001 when the tagging program began.

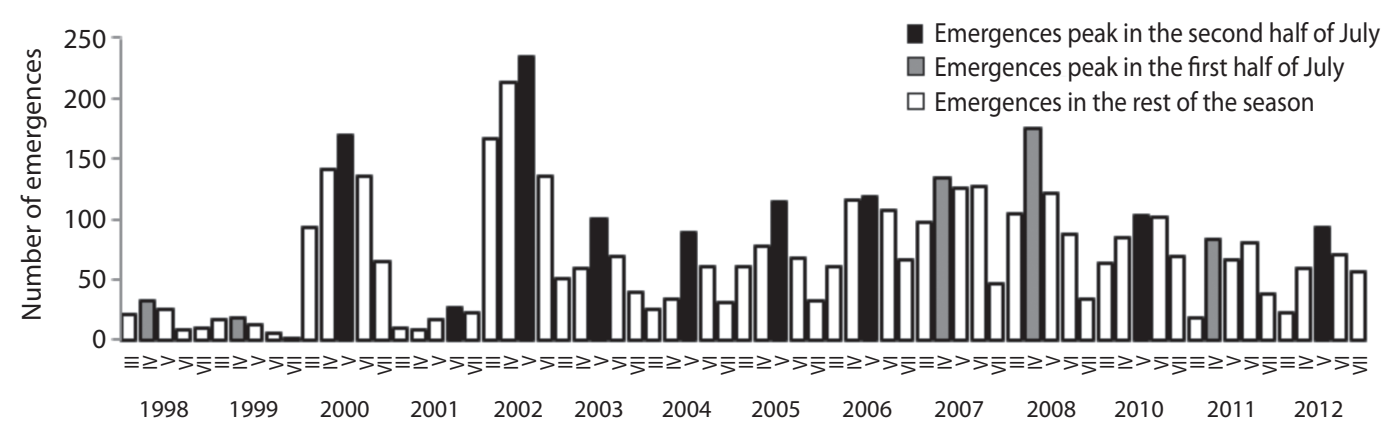

Fifteen days intervals per nesting season ${ }^{1,2}$

Fig. 2. Number of emergences by green turtles (Chelonia mydas) during the nesting season at the Peninsula of Guanahacabibes, Cuba.

${ }^{1}$ III: second half of June, IV: July, first half, V: July, second half, VI: August, first half, VII: August, second half.

${ }^{2}$ Year 2009 was not included because of insufficient data. 


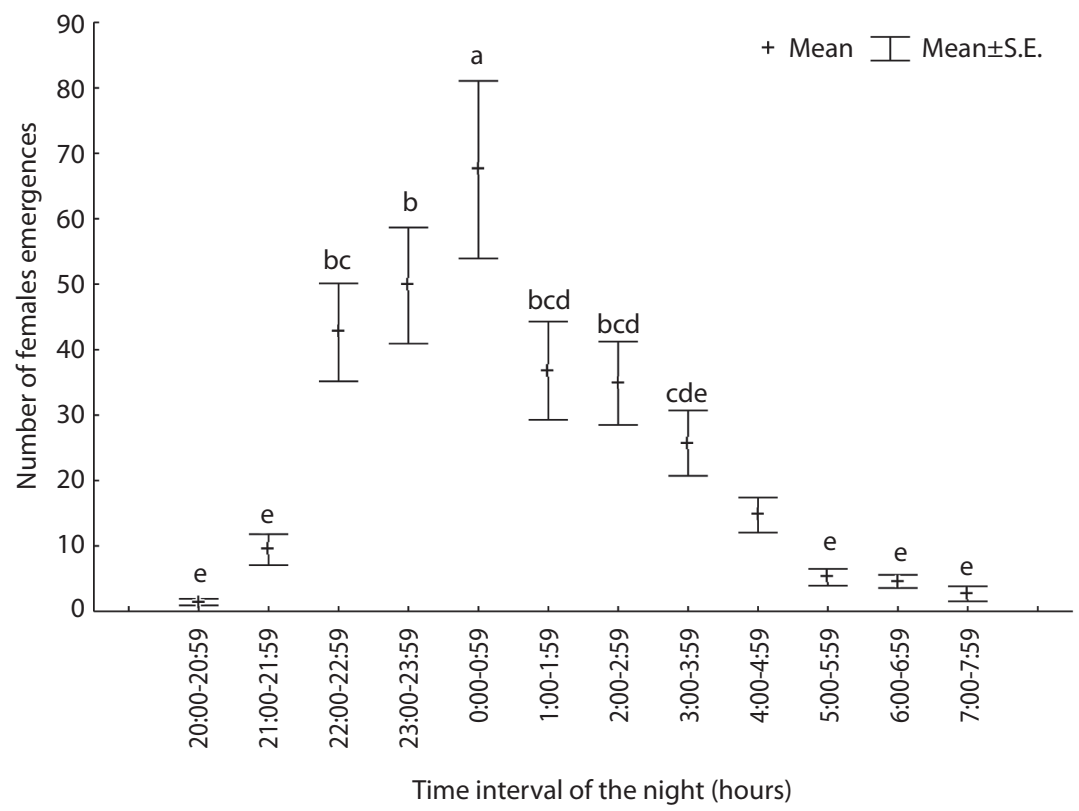

Fig. 3. Number of females emergences at hourly intervals of the night. Similar letters represents statistically homogenous groups. SE: Standard error.

Higher nesting numbers per unit area were observed at the smallest beaches: Caleta, Antonio, Perjuicio and La Barca (Table 2), with the exception of Resguardo. Four of the five index beaches had the highest nesting numbers.

Variation within beaches was observed in reproductive success. The maximum number of nests was observed at a $6-9 \mathrm{~m}$ interval of distance from the mean high tide line but the hatching success was higher further inland, beyond $50 \mathrm{~m}$. Nevertheless, combining these two factors, hatchling production was highest in the same distance interval as the nests which exceeded 27000 individuals for all years combined (Fig. 4).

There was no significant variation in the mean body size of nesting females between years. More than $50 \%$ of females fell within the

TABLE 2

Density of green turtles (Chelonia mydas) at each monitored beach in the Guanahacabibes Peninsula

\begin{tabular}{lcc} 
& \multicolumn{2}{c}{ Mean \pm Standard Deviation. } \\
& Nest $/ \mathrm{km}^{2}$ & Nests $/ \mathrm{km}$ \\
Caleta $[100 \mathrm{x} 9 \mathrm{~m}]^{1}$ & $0.0559 \pm 0.0642$ & $616.36 \pm 582.57$ \\
Antonio $[200 \times 9 \mathrm{~m}]$ & $0.0195 \pm 0.0111$ & $292.73 \pm 166.14$ \\
Perjuicio $[500 \times 15 \mathrm{~m}]$ & $0.0082 \pm 0.0121$ & $99.51 \pm 115.13$ \\
La Barca $[500 \times 10 \mathrm{~m}]$ & $0.0075 \pm 0.0069$ & $95.64 \pm 80.41$ \\
Resguardo $[150 \times 15 \mathrm{~m}]$ & $0.0048 \pm 0.0125$ & $45.00 \pm 112.00$ \\
Canas $[800 \times 12 \mathrm{~m}]$ & $0.0030 \pm 0.0020$ & $29.20 \pm 28.44$ \\
Holandés $[1020 \mathrm{x} 10 \mathrm{~m}]$ & $0.0015 \pm 0.0017$ & $18.19 \pm 18.75$ \\
Cayuelos $[800 \times 12 \mathrm{~m}]$ & $0.0006 \pm 0.0009$ & $9.09 \pm 14.75$ \\
C. Larga $[800 \times 10 \mathrm{~m}]$ & $0.0006 \pm 0.0007$ & $8.75 \pm 10.72$ \\
\hline
\end{tabular}

1. Values used to calculate area [length $\mathrm{x}$ wide in meters]. 


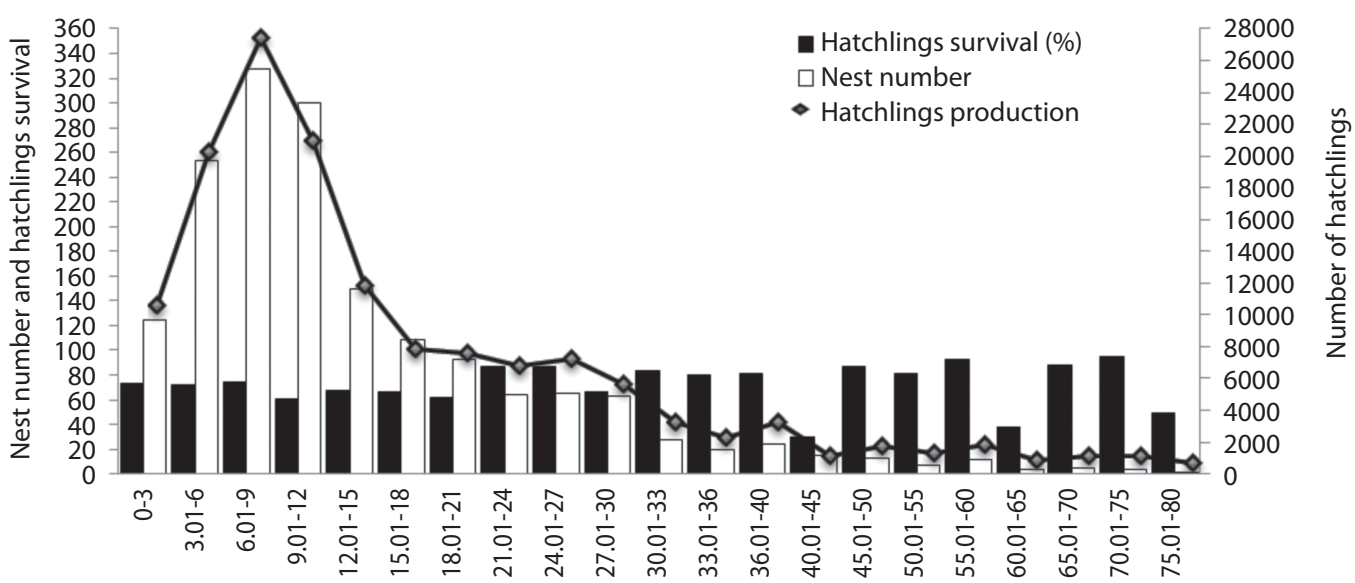

Distance from the nest to the high tide line $(m)$

Fig. 4. Reproductive success of green turtle as a function of distance from mean high tide at the Guanahacabibes Peninsula, Cuba.

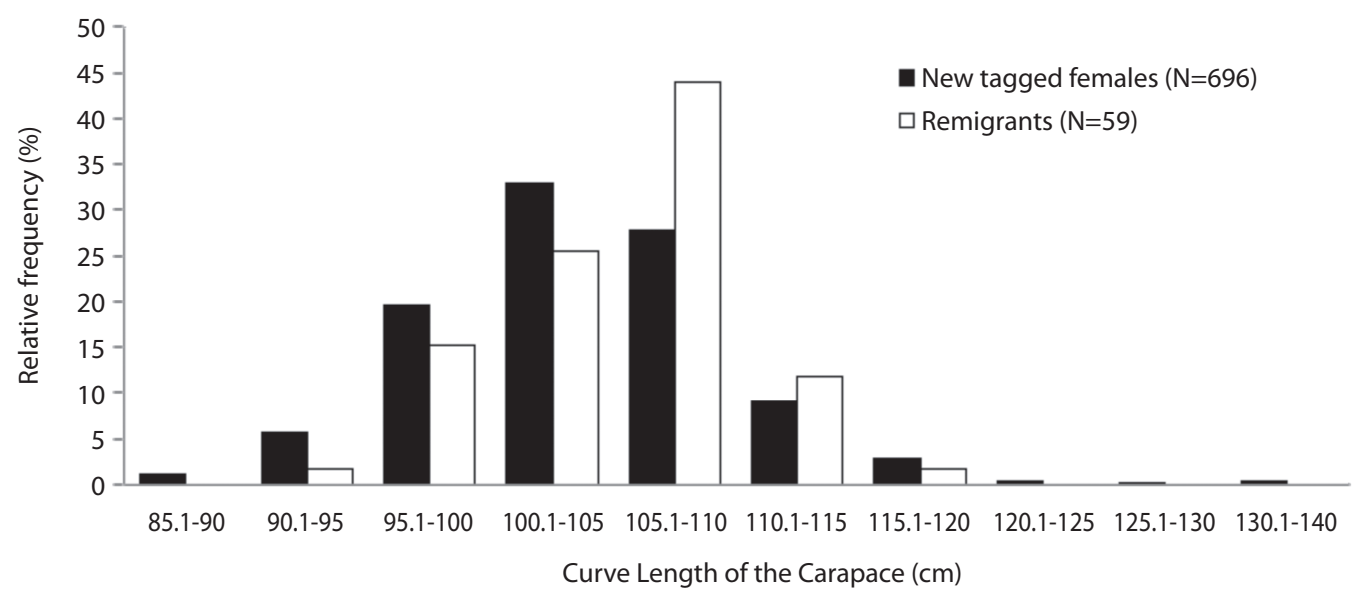

Fig. 5. Size distribution of the curved carapace length of new tagged and remigrants green turtles nesting at Guanahacabibes Peninsula, Cuba.

size interval of 100-110cm CCL (Fig. 5), which includes a population mean of $104.49 \mathrm{~cm}$ CCL. Nevertheless there is a difference between newly tagged females and remigrants because the first group had more females in the 100$105 \mathrm{~cm}$ size interval, whereas the second had more females in the $105-110 \mathrm{~cm}$ size interval $\left(\mathrm{X}_{(5)}^{2}=19,6 ; \mathrm{p}<0,01\right)$.

The remaining morphometric measures of C. mydas are presented in table 3. Although most of the values are very close to the mean value according to the confidence interval, there is a wide range of values for all the measurements as we can determine from the difference of the minimum and maximum values.

\section{DISCUSSION}

Green turtles nesting in Guanahacabibes have a remigration interval comparable to that 
TABLE 3

Morphometric measures of green turtles (Chelonia mydas) nesting at Guanahacabibes Peninsula, Cuba

\begin{tabular}{lcccc}
\multicolumn{1}{c}{ Measurements $(\mathrm{cm})$} & $\mathrm{N}$ & Mean $\pm^{1}$ & Minimum & Maximum \\
Straight Carapace Length & 607 & $95.64 \pm 0.43$ & 34.00 & 128.00 \\
Curve Carapace Width & 780 & $92.95 \pm 0.38$ & 41.00 & 120.00 \\
Straight Carapace Width & 604 & $73.57 \pm 0.42$ & 32.00 & 110.00 \\
Track width & 708 & $107 \pm 0.58$ & 32.00 & 164.00 \\
Head Length & 265 & $19.6 \pm 0.35$ & 14.00 & 32.00 \\
Head Width & 67 & $15.54 \pm 0.88$ & 10.00 & 25.00 \\
\hline
\end{tabular}

1. Confidence interval.

reported by Márquez (1996: 2.3yr) although there was an increase in the last three years. Between reproductive seasons, herbivorous green turtles forage in near shore Cuban waters and beyond (Moncada \& Nodarse, 1998) where they accumulate the necessary energy reserves to sustain vitelogenesis (Broderick, Glen, Godley \& Hays, 2003). Reproductive periodicity is related to the quality and quantity of available food (Bjorndal, 1980), and a suite of exogenous (e.g. photoperiod) and endogenous (e.g. hormonal or fat levels) variables (Wibbels, Owens, Limpus, Reed \& Amoss, 1990). Broderick, Godley \& Hays (2001) suggested that variations in the quantity and quality of seagrass can produce dramatic fluctuations in the number of annual nesting females. These environmental variations are assumed to contribute to the observed fluctuations in the number of turtles that come to lay eggs in Cuba every year.

Nodarse et al. (2000) reports a predominant two-year nesting cycle for the Guanal Beach population on the South coast of Isla de la Juventud, Cuba. In our study, a majority of nests were typically produced on alternate year cycles until the year 2002. After that, there was a continuous increase in annual nest number every year until 2008. Nevertheless, the same pattern has been observed in longer sequences, such as those observed in the Tortuguero population (Tröeng \& Rankin, 2005). We also document a predominant two-year remigration interval among tagged females, which is congruent with the first six years of biennial trend. Interestingly, during the period of increasing annual nesting, the remigration interval shortens. Considering that sea turtles are a long-lived species these suggest that our temporal sample (14 years) may be insufficient to accurately describe the population level periodicities. A strong biennial cycle has been observed in other green turtle populations (Broderick et al., 2001). While it has never been fully explained it is probably related to the biological factors explained above.

Intra-seasonal variation in nesting activity was similar to that reported elsewhere (Aiken et al., 2001), including patterns of nest site selection that would appear to reduce the impact of an unpredictable environment on hatchling production (cf. Eckert 1987). It was observed that green turtles lay fewer eggs at the beginning of the reproductive season. This can be a consequence of an increase in the efficiency or capacity in the process related to vitelogenesis and the possibility that, as the season progresses, turtles feed less, liberate space in the body cavity where they may accommodate more eggs (Broderick et al., 2003). At the end of the season, the nesting frequency decreases, which is presumably related to the depletion of egg production, as the female energy reserves become exhausted.

The concentration of the highest number of emergences around midnight coincides with the pattern reported by Miller (1996) for $C$. mydas. The pattern could respond to a selection process optimizing the chance of completing the nesting process in advance of dawn, thereby 
reducing the depredation or heat exposure risks (Azanza et al., 2006).

Although there have been several attempts to define the selection criteria of a "good" nesting beach, the actual reason remains a mystery (Mortimer 1990). Some authors have suggested that nesting sites are spread out and may even be selected at random within a suite of potentially adequate nesting beaches (Mrosovsky, 1983; Hays et al., 1995). However, most researchers agree on a group of factors that strongly influence the selection of the nesting site such as: topography, slope, microhabitat, submerged stones (Hays et al., 1995; Mortimer, 1995), terrestrial vegetation (Hays \& Speakman, 1993; Mortimer, 1995), temperature (Stoneburner \& Richardson, 1981), competition among species, (Whitmore \& Dutton, 1985) and structural properties of the sand (e.g. compressibility, particle characteristics) (Mortimer, 1990, 1995). Human interference (Witherington, 1992), especially the presence or absence of artificial lighting (Mortimer, 1995; Salmon et al., 1996; Witherington \& Martin, 1996) is also a determinant factor in nesting site selection.

Variation among beaches for one or several of these factors could determine the differential in nesting that exists in the Peninsula, and the existence of beaches which consistently present the highest nesting numbers. Our results coincide with those of Aiken et al. (2001), in that the highest nesting abundances occur on the smaller beaches, which indicate that beach condition is more important than the length. Also, the lack of dissimilarity found in the comparison among all nesting beaches based only on length or sandy area could be the result of the similarity in the width of all of the beaches.

In Guanahacabibes Peninsula, the highest nesting concentrations occur at the vegetation zone (Azanza et al., 2003), which increases clutch survival (Azanzaet al., 2006). Other studies observe that vegetation plays an important role in nest site selection (Cheng 2000). Vegetation reduces erosion (Mortimer, 1995; Bjorndal \& Mortimer, 1982) and root systems allow for ventilation (Mortimer, 1995). In contrast, nests laid within $3 \mathrm{~m}$ of mean tide line are more susceptible to flooding during high tides and strong surf (Mrosovsky, 1983), as well as shifts in gaseous exchange, humidity and temperature that are fatal to the developing embryo (Azanza et al., 2006). This may explain why nesting near the mean tide line is less frequent.

Curved carapace lengths of green turtles in the Guanahacabibes Peninsula fall within a global range of values $(71.1 \mathrm{~cm}-139.5 \mathrm{~cm})$ for this species reported by Márquez (1996) as well as within the range of values reported for Cuban populations (Nodarse et al., 2000). In contrast, the mean straight carapace length $(94.6, \mathrm{~N}=726)$ is smaller than the one reported by Miller (1996) for the species $\left(\mathrm{SCL}=99.1 \mathrm{~cm}, \mathrm{SD}=1.9, \mathrm{~N}_{\text {populations }}=22\right)$ and for other areas (Bjorndal \& Carr, 1989, for Costa Rica: $\mathrm{SCL}=100.2 \mathrm{~cm}, \mathrm{SD}=5.0, \mathrm{~N}=2107$, Chen \& Cheng, 1995, for Wan-An Island, Taiwan: $\mathrm{SCL}=96.6 \mathrm{~cm}, \mathrm{SD}=7.0, \mathrm{~N}=14$ ). It is possible that the Cuban studied population is younger, with a large number of new recruits, which is consistent with the large number of newly tagged females and the low number of remigrants at peninsula study sites, even after 11 years of intensive tagging.

Results from this study are only a first approximation to characterize the reproductive values of the Guanahacabibes populations. However, this work highlights the importance of the population within the Cuban archipelago and described important characteristics of its nesting ecology. The temporal variation found points to the need for long-term monitoring before questions about the reproductive biology of the species can be resolved. The information herein presented has great value for establishing conservation priorities within the context of national management plans, and for efficient monitoring and protection of nesting beaches.

\section{ACKNOWLEDGMENTS}

This research was supported by World Wildlife Fund Program in Cuba, Ocean Foundation, International Ocean Institute and 
Southern Archipelago United Nation Program for Development project. We will like to acknowledge also to the Universidad Autónoma de México (UNAM)-Universidad de La Habana join Ph.D. program and to The Academy of Science for the Developing World (TWAS). We especially thank the more than 1800 volunteers that collected field data during these 14 years.

\section{RESUMEN}

La colonia de Tortuga verde (Chelonia mydas) que anida en la Península de Guanahacabibeses es una de las más grandes del archipiélago cubano pero existe poca información disponible sobre la misma. Por ello utilizamos la variación espacial y temporal de la anidación así como el éxito reproductivo y las características morfométricas de las hembras grávidas para realizar la primera caracterización ecológica de esta colonia. Se estudiaron nueve playas durante 14 años (1998-2012) desde mayo hasta septiembre (pico de anidación). Estas se dividieron en dos categorías: índices y secundarias. Las hembras fueron medidas y marcadas para comparar las nuevas hembras marcadas (823) con las remigrantes (140). Se detectó una variación temporal en la anidación a tres niveles: interanual, dentro de la temporada y durante la noche. Se observa un ciclo bienal en los primeros seis años, luego un incremento anual (2003-2008) seguido por un período de decrecimiento en las anidaciones (2010-2012). Dentro de la temporada se encontró un pico en el mes de julio aunque cambia de la primera quincena a la segunda en años diferentes y la hora de emergencia preferentemente de 22:00-02:00hr. En la variación espacial, las playas pequeñas tuvieron mayor densidad de anidación, especialmente entre los 6-9m hasta la línea media de marea alta, donde se maximiza la producción de neonatos, aunque el éxito de emergencia de los neonatos se mantuvo como promedio por encima del $80 \%$ en toda la playa. Morfométricamente las hembras remigrantes resultaron mayores como promedio que las marcadas por primera vez. Estos resultados son una primera aproximación para la caracterización de la colonia de Guanahacabibes pero tienen gran valor para establecer prioridades de conservación dentro del contexto de los planes de manejo nacionales así como para garantizar un monitoreo eficiente y la protección de las playas de anidación.

Palabras clave: tortuga verde, ecología, anidación, éxito reproductivo, Cuba.

\section{REFERENCES}

Aiken, J. J., Godeny, B. J., Broderick, A. C., Austin, T., Ebanks-Petrie, G., \& Hays, G. C. (2001). Two hundred years after a commercial marine turtle fishery: the current status of marine turtles nesting in the Cayman Islands. Oryx, 35, 145-152.

Azanza, J., Ibarra, M. E., Espinosa, G., Díaz, R., \& González-Sansón, G. (2003). Conducta de anidación de la Tortuga Verde (Chelonia mydas) en las Playas Antonio y Caleta de los Piojos de la Península de Guanahacabibes, Pinar del Río, Cuba. Revista de Investigaciones Marinas, 24, 231-240.

Azanza, J., Ruisanchez, Y., Ibarra, M. E., Ruiz, A., Luis, C.Y., \& Colectivo de estudiantes de la Facultad de Biología. (2006). Indicadores del éxito reproductivo de la tortuga verde (Chelonia mydas) en tres playas de la Península de Guanahacabibes, Pinar del Río, Cuba. Revista de Investigaciones Marinas, 27, 69-78.

Azanza, J. (2009). Estrategia reproductiva de la tortuga verde, Chelonia mydas, (Testudines, Cheloniidae) y su impacto en la estructura genética de áreas de anidación del occidente del archipiélago cubano. (Doctoral dissertation, Havana University, La Habana, Cuba).

Balazs, G. H. (1999). Factors to consider in marine turtles' tagging. In K. L. Eckert, K. A. Bjorndal, F. A. Abreu-Grobois, \& M. Donnelly (Eds.), Research and Management Techniques for the Conservation of Sea Turtles, (pp.116-125). Washington, DC: IUCN/SSC Marine Turtle Specialist Group Publication.

Bjorndal, K. A. (1980). Dermography of the breeding population of the green turtle, Cheloniamydas, at Tortugero, Costa Rica. Copeia, 1980, 525.

Bjorndal, K. A., \& Mortimer, J. A. (1982). The consequence of herbivory for the life history pattern of the Caribbean green turtle, Chelonia mydas. In K. A. Bjorndal (Ed.). Biology and Conservation of Sea Turtles, pp.111-116. Washington DC: Smithsonian Institution.

Bjorndal, K. A., \& Carr, A. (1989). Variation in clutch size and egg size in the green turtle nesting population at Tortuguero, Costa Rica. Herpetologica, 45, 181-189.

Bolten, A. B. (1999).Techniques for Measuring Sea Turtles. In K. L. Eckert, K. A. Bjorndal, F. A. Abreu-Grobois, \& M. Donnelly (Eds.), Research and Management Techniques for the Conservation of Sea Turtles, (pp.110-114).Washington, DC: IUCN/SSC Marine Turtle Specialist Group Publication. 
Broderick, A. C., Godley, B. J., \& Hays, G.C. (2001). Trophic status drives inter-annual variability in nesting numbers of marine turtles. Proceedings of the Royal Society, 268, 1481-1487.

Broderick, A. C., Glen, F., Godley, B. J., \& Hays, G. C. (2003).Variation in reproductive output of marine turtles. Journal of Experimental Marine Biology and Ecology, 288, 95-109.

Chen, T. H., \& Cheng, I. J. (1995). Breading biology of the green turtle, Chelonia mydas (Reptilia: Cheloniidae), on Wan-An Island, PengHu archipelago, Taiwan. I. Nesting ecology. Marine Biology, 124, 9-15.

Cheng, J. (2000). Post-nesting migrations of green turtles (Chelonia mydas) at Wan-An Island, Penghu Archielago, Taiwan. Marine Biology, 137, 747-754.

Eckert, K. L. (1987). Environmental unpredictability and leatherback sea turtle (Dermochelys coriacea) nest loss. Herpetologica, 43, 315-323.

Espinosa, G., Hernández, G., Jager, M., Olavarría, K., Ibarra, M. E., Masselot, M., \& Deutch, J. (1999, March). Genetic identification of a nesting colony of green turtles, Chelonia mydas, from the western Cuban shelf. In H. Kalb \& T. Wibbels (Chair), Proceedings of the $19^{\text {th }}$ Annual Symposium on Sea Turtle Biology and Conservation. Symposium conducted at NOAA Technical Memorandum. NMFS-SEFSC-443, Texas, USA.

Hays, C. G., \& Speakman, J. R. (1993). Nest placement by loggerhead turtles, Caretta caretta. Animal Behavior, 45, 47-53.

Hays, C. G., Mackay, A., Adams, C. R., Mortimer, J. A., Speakman, J. R., \& Boerma, M. (1995). Nest site selection by sea turtles. Journal of Marine Biology, 75, 667-674

Ibarra, M. E., Espinosa, G., Angulo, J., Pacheco, J., \& Students from the Faculty of Biology (Univ. of Havana) (1999, March). University project on the study and conservation of sea turtles. Preliminary results and future plans. In H. Kalb \& T. Wibbels (Chair), Proceedings of the 19th Annual Symposium on Sea Turtle Biology and Conservation. NOAA Technical Memorandum. NMFS-SEFSC-443.

Ibarra, M. E., Díaz-Fernandez, R., Nodarse, A., Azanza, J., Angulo-Valdés, J., Espinosa, G., \& Pacheco, J. (2002). Project Update: University Project for the Study and Conservation of Cuban Sea TurtlesCompletion of Year 3. Marine Turtle Newsletter, 95, $18-20$.

IUCN. (2001). IUCN Red List Categories and Criteria: version 3.1 (30 pp.). IUCN Species Survival Commission, Gland, Switzerland.
Márquez, R. (1996). Las tortugas marinas y nuestro tiempo. México: Fondo de Cultura Económica.

Martín, M. E. I., Angulo, J., Espinosa, G., Pacheco, J., Moncada, F., Nodarse, G., \& Escobar. E. (1998, December). University project on the study and conservation of sea turtles. In F.A. Abreu-Grobois, R. Briseño, R. Márquez \& L. Sarti (Chair), Proceedings of the 17th Annual Symposium on Sea Turtle Biology and Conservation. NOAA Technical Memorandum. NMFS-SEFSC-436, Florida USA.

Martín, M. E. I., Angulo, J., Espinosa, G., Pacheco, J., Moncada, F., Nodarse, G., \& Escobar, E. (1999). University project on the study and conservation of sea turtles. Marine Turtle Newsletter, 84, 11-12.

Miller, J. D. (1996). Reproduction in sea turtles. In P. L. Lutz, \& J. A. Musick (Eds.). The Biology of Sea Turtles (pp.51-82). Boca Raton, Florida: CRC Press.

Moncada, F., \& Nodarse, G. (1983). Informe nacional sobre la actividad desarrollada por Cuba en el estudio y conservación de las tortugas marinas (4 pp). Centro de Investigaciones Pesqueras, Dept. Cría experimental, Ministerio de la Pesca, Habana.

Moncada, F., \& Nodarse, G. (December, 1998). The green turtle (Chelonia mydas) in Cuba. In S. P. Epperly, \& J. Braun (Eds.). Proceedings of the $17^{\text {th }}$ Annual Sea Turtle Symposium. NOAA Technical Memorandum. NMFS-SEFSC-415.

Mortimer, J. A. (1990). The influence of beach sand characteristics on the nesting behavior and clutch survival of green turtles (Chelonia mydas). Copeia, 1990, 802-817.

Mortimer, J. A. (1995). Factors influencing beach selection by nesting sea turtles. In K. Bjorndal (Ed.). Biology and Conservation of Sea Turtles (pp.45-52). Washington, DC: Smithsonian Institution Press.

Mrosovsky, N. (1983). Ecology and nest site selection of leatherback turtles, Dermochelys coriacea. Biological Conservation, 26, 47-56.

Nodarse, G., Moncada, F., Meneses, A., \& Rodríguez, C. (2000). Long-Term monitoring of nesting of the green sea turtle (Chelonia mydas) in the Southwest platform of Cuba. In F. A. Abreu-Grobois, R. Briceño-Dueñas, R. Márquez, \& L. Sarti (Eds.). Proceeding of the $18^{\text {th }}$ Annual Sea Turtle Symposium (pp.68-69). NOAA Technical Memorandum. NMFS-SEFSC-436.

Nodarse, G., Rivera, J., Moncada, F., Díaz, R., Rodríguez, C., Morales, E., \& Avila, O. (2002). Marine turtles nesting in the Cuban Archipelago. In J. A. Seminoff (Ed.). Proceeding of the $22^{\text {nd }}$ Annual Sea Turtle Symposium (pp. 155). NOAA Technical Memorandum. NMFS-SEFSC-503. 
Salmon, M., Reiners, R., Lavin, C., \& Wyneken, J. (1996). Behavior of logger head sea turtles on an urban beach. I. Correlates of nest placement. Journal of Herpetology, 29, 560-567.

Stoneburner, D. L. \& Richardson, J. L. (1981). Observations on the role of temperature in loggerhead turtle nest site selection. Copeia, 1981, 238-241.

Tröeng, S., \& Rankin, E. (2005). Long-term conservation efforts contribute to positive green turtle Chelonia mydas nesting trend at Tortuguero, Costa Rica. Biological Conservation, 121, 111-116.

Whitmore, C. P., \& Dutton, P. H. (1985). Infertility, embryonic mortality and nest-site selection in leatherback and green sea turtles in Suriname. Biological Conservation, 34, 251-272.
Wibbels, T., Owens, W. D., Limpus, J. C., Reed, C. P., \& Amoss, S. M. (1990). Seasonal changes in serum gonadal steroids associated with migration, mating and nesting in the loggerhead sea turtle (Caretta caretta). General Comparative Endocrinology, 79, 154-164.

Witherington, B. E. (1992). Behavioral responses of nesting sea turtles to artificial lighting. Herpetologica, 48, 31-39.

Witherington, B. E. \& Martin, R. E. (1996). Understanding, Assessing, and Resolving Light Pollution Problems on Sea Turtle Nesting Beaches. (FMRI Technical Report TR-2). St. Petersburg, Florida: Florida Marine Research Institute. 
